\title{
The Catholic Church in Tunisia: a transliminal institution between religion and nation
}

The Journal of North African Studies, forthcoming 2019

\author{
Alexis Artaud de La Ferrière \\ Lecturer, SOAS, University of London \\ Chercheur associé à l'étrange, GSLR (Groupe Sociétés Religions Laïcités), EPHE/CNRS \\ aa186@soas.ac.uk
}

\begin{abstract}
Since Tunisian national independence in 1956, the Catholic Church has maintained its presence in Tunisia despite the demographic collapse of Catholics in the country and despite the Church's historic ties to the French state under the protectorate regime. The Church in Tunisia succeeded in maintaining a position within the country after independence by transforming itself from a triumphalist colonial institution into what can be termed a transliminal institution. Situated in a liminal position with regards to both the Tunisian and the Catholic worlds, the Church in Tunisia after independence continued to exist through a constant process of translation and mediation between these two spaces. This article examines the historical development of this situation and the key dimensions which constitute the institutional Church's transliminality.
\end{abstract}

\section{Key words}

Catholicism, Religion, National identity, Tunisia, Transnationalism, Transliminality 


\section{Introduction}

In 2014, I attended (as a spectator) an international break dance competition sponsored by the energy drink company Red Bull. The event was held in the Carthage Acropolium, a vast neoByzantine-Moorish edifice on the heights of Byrsa, which currently serves as a cultural centre in this wealthy northern suburb of Tunis. However, prior to the Modus Vivendi signed between the Tunisian Republic and the Holy See in 1964, this had been a Roman Catholic Basilica dedicated by Cardinal Lavigerie to Saint Louis, the Capetian French monarch who died on that approximate spot during the Eighth Crusade in 1270. The site had also served as Lavigerie's own mausoleum before his remains were transferred to Rome following the deconsecration of the site. Painted inside the nave, one can still read a phrase attributed to Pope Leo IX that reflects the importance of this site in the history of the early Church: Sine dubio post Romanum Pontificem primus archiepiscopus et totius africae maximus Metropolitanus est Carthaginiensis Episcopus (Undoubtedly, after the Roman Pontiff, the highest Archbishop and Metropolitan for all Africa is the Bishop of Carthage). In this spirit, it was Leo's successor and namesake (the thirteenth of the name) who re-established the seat of Carthage as an archiepiscopate in 1884.

Popes Leo notwithstanding, watching b-boys dance under that same nave in 2014, one was rather inclined to think that the Carthaginian Church was rendered to history, its fate definitively sealed with the dissolution of the French Protectorate of Tunisia in 1956. Indeed, in that year an estimated 250,000 Catholics resided in Tunisia, regularly attending services in one of 78 parishes served by 230 priests (Cugusi 2014:355). By 1957 the Catholic population had dropped to 100,000 ; by 1964, the year of the Modus Vivendi which ceded most Church property to the State, only 20,000 Catholics remained, out of which only 7,000 were considered to attend services on a regular basis, served by 90 priests (ibid). Today, a few 
thousand Catholics reside in Tunisia served by approximately 40 priests (Archdiocese of Tunis 2018).

Moreover, such an evening might have seemed to (anecdotally) vindicate one or another theory of the globalisation of secularisation (Norris and Inglehart 2011, Casanova 2013), as contestants from across North Africa converged on this site to perform a secular dance style pioneered in the United States in an event sponsored by an Austrian beverage company. Such an event presents a facet of Tunisian society penetrated by secular individualism, consumerism, and the deterritorialization of culture. Yet, elsewhere in Tunisia, the dual (but distinct) phenomena of Ennahda's electoral successes (Lefèvre 2015) and the growth of revolutionary Salafism (Torelli et al. 2012) seemed to indicate a return of the religious with transnational horizons rather than an inroad of secularisation into the national self-narrative. Another, less visible, but notable phenomenon since at least the mid-1990's, and especially since the mid-2000's, was the growth of non-denominational Protestant Churches which attract increasing number of adherents in Tunisia (Boissevain 2013, 2014a) and in Algeria (Direche 2009). This trend reflects the incorporation of Maghrebi societies within the globalisation of the Evangelical (or neo-Evangelical) movement (Direche 2011). Beckford (2003) argues that globalisation opens opportunities for faith groups with universalist or proselytising agendas to penetrate previously insular territories, an analysis which appears confirmed in the Tunisian case.

The triple phenomena of the secularisation of certain sectors of Tunisian society, the internal fragmentation of Tunisian Islam, and the individualisation of religious identifications amongst Tunisians suggest that the religious landscape in the country is rapidly evolving towards a model that is increasingly transnational, pluralistic, and individualised. Such characteristics are not distinct to Tunisia, but rather reflect the degree to which religion (amongst other things) in the region is affected by dominant trends within global society. 
However, such trends pull in several distinct directions making the future of religion in North Africa fundamentally unpredictable (Beyer 1999). Beyond the question of individuals' religious identification (or lack thereof), the question of what impact such evolutions have on political communities and national identities highlights the complexity of the relationship between religion and nationhood, a relationship conditioned by forces both local and global. It is unsatisfactory to assume that a particular religious identification necessarily correlates in a certain way with feelings of national identification (Artaud de La Ferrière 2018).

Upon preliminary inspection, Catholicism appears to be a marginal force within the evolution of religiosity in Tunisia; more of a historical hangover than a significant future player. It has a small number of active adherents, almost all of them foreign. It does not attract large numbers of Tunisian converts as seems to be the case with Protestant Churches, partly because it does not seek them. Although it has a recognised status, it is not a significant institutional actor in Tunisian national politics. Its material, human, and financial resources are modest, limiting its capacity to directly intervene in Tunisian civil society.

However, despite its demographic collapse and its ties to the former Protectorate regime, Catholicism has maintained a foothold in Tunisia and even solidified its institutional position within the country by obtaining recognition from the Tunisian state. What is striking about the Catholic Church in Tunisia is not its decline, which was predictable in the postcolonial context, but its resiliency and adaptability. The Church has maintained a position within Tunisian national society that is hugely disproportionate in comparison to its effective constituency within that nation. It has been able to do so as a result of its responsiveness to changes both in its local socio-political environment and to broader theological and pastoral evolutions in the transnational Catholic world. Indeed, from an early stage following national independence and the subsequent disappearance of a genuine "parochial civilisation" (Lambert 1985), the Church in Tunisia drew on contemporaneous developments within 
Catholic social doctrine and Catholic teachings on interfaith dialogue, and elected to reorient its core mission, guided by the twin policies of methodical discretion and secular engagement in civil society. In effect, the Church in Tunisia succeeded in maintaining a position within the country after independence by transforming itself from a triumphalist colonial institution into what will be termed a transliminal institution. By this term, I mean to identify institutions which exhibit two key characteristics. First, being situated in a liminal or peripheral position with regards to two or more discrete institutional and cultural frameworks: neither wholly of one or of another. Second, where such an institution deploys the majority of its activities towards mediating relations or translating meanings between those frameworks. The aim of this article is to account for this historical transformation and to develop an analysis of the Catholic Church in Tunisia as a typological example of a transliminal institution. The first section of the article will discuss the post-colonial historical background of the Church in Tunisia in order to analyse how and why the Church developed this particular profile. This is followed by a brief presentation of the contemporary array of the Church: its demographic composition, its regional implantation, its institutional standing. The third section constitutes the core discussion of the Church's transliminality. Here, the Church's liminal position and mediating function is analysed through three successive dimensions: the Church's self-narrative through scriptural references; national identification and in relation to nationhood within the Church; and finally, the meaning of evangelisation and mission for Catholic actors within the Tunisian context.

This article draws on ethnographic fieldwork carried out in July 2018 across several locations in Tunisia. During this period, I conducted semi-structured interviews with 29 Catholic actors residing regularly in Tunisia: priests, religious brothers and sisters, and lay members of secular orders. The choice was deliberately made to focus research on persons present in Tunisia in an official capacity within the institutional Catholic Church because the aim here is 
to better understand the position and identity of the institutional church in this country. It was therefore required of interviewees that they be self-reflexive about themselves qua Catholic actors in this missionary context of religious alterity. What sense of mission do Catholics attribute to their presence in Tunisia? How do Catholics identify with Tunisia and Tunisians? What legitimate role do they attribute to the Church in Tunisia? Is the Catholic imaginary of Tunisia which emerges from these questions itself undergoing a process of transformation as both Tunisian society and the internal sociology of the Church in Tunisia evolve as a result of the local and global trends previously outlined?

This core data set was supplemented with semi-structured interviews conducted with seven lay Catholics, two of whom were Tunisian converts, as well as observations conducted during religious services and during a social event held for Catholic students in the district of La Manouba. Interviewees were selected from all of the Church's regional implantations in the country, with the exception of the island of Djerba. ${ }^{1}$ Additionally, I also surveyed the holdings of the archives of the Catholic Archdiocese in Tunis and received printed materials from the personal archives of Fr Dominique Tommy-Martin and from Fr Jean Fontaine, M. Afr.

\section{The historical construction of the church as a transliminal institution}

\section{The post-colonial turn: from triumphalism to methodical discretion}

The transliminal profile of the Catholic Church in Tunisia is the result of radical changes which occurred within Tunisian society and within the Church following national independence in 1956. It is beyond the scope of the present article to provide an overarching

\footnotetext{
${ }^{1}$ Details about the interviewees are provided in the bibliography; in the case of individuals who have an official capacity within the Church I have provided their full names whilst only the first names are provided for lay Catholics.
} 
historical survey of the Catholic Church in Tunisia. The most up-to-date such survey currently available is Maria Chiara Cugusi's well-researched doctoral thesis (2014) which spans from the establishment of the French Protectorate in 1881 to the years immediately following the fall of the Ben Ali regime in 2011; this was subsequently published as a monograph in Italian (2016). Another doctoral thesis by Saloua Ouerghemmi (2011) studies the architecture and material history of the Catholic Church in Tunisia during the protectorate period. Fr François Dornier, M. Afr., published a monograph in French (2000) which principally draws on the Archdiocese archival holdings, the principle interest of which is to be found in the second section which offers details concerning the former parishes in existence prior to 1964 and the third section which surveys the numerous congregations and religious orders present in Tunisia between the Protectorate period and the end of the XXth century. A more dated work but also more focused in scope, Michel Lelong's, M. Afr., doctoral thesis (1970) is particularly rich in its treatment of Catholic-Muslim relations between 1930 and 1968. Lelong's chosen chronology is illuminating, and it is useful to review certain key events of that period in order to better understand the present array. 1930 marks the apex both of Catholic triumphalism and of the Church's complicity with French imperialism in North Africa when the Eucharistic Congress was held in Carthage, drawing thousands of Catholics from around the world for a week of mass religious and patriotic celebrations which drew the ire of many Tunisian nationalists including Habib Bourguiba (Alexandropoulos 2009). 1968 marks the definitive end of this period. In that year, Mgr Callens (then Prelate of Tunis) organised a diocesan assembly (often referred to by the participants as a Synod) to reassess the mission of the Church in light of national independence, a reformed status following the 1964 Modus Vivendi, and the progressive departure of Christian parishioners. Between 1930 and 1968, the Church's self-identity thus radically shifted from a position of colonial triumphalism, symbolised by the monumental 
churches erected in Carthage and Tunis city centre, to a position of methodical discretion in the religious domain whilst at the same time engaging more directly with Tunisian civil society in the secular domain. This shift resulted from a combination of external and internal factors.

Externally, national independence in 1956 and the subsequent nationalisation of agricultural lands held by colonists in 1964 led to the departure of the majority of the European population, which vastly reduced the number of Church members. Indeed, in 1956 prior to independence, an estimated 250,000 Catholics resided in Tunisia, and attended services in one of 78 parishes served by 230 priests (Cugusi 2014:355). By 1957 the Catholic population had dropped to 100,000 and by 1964 , the year of the Modus Vivendi, there were only 20,000, out of which only 7,000 of which were considered to attend services on a regular basis, served by 90 priests (ibid).

The Modus Vivendi itself radically changed the scope and nature of the Church's institutional standing in the country (Soumille 2003). In 1959, Bourguiba opened negotiations with the Holy See to redefine the Church's legal standing in the newly independent country and to negotiate the nationalisation of Church property, leading to the ratification of a bilateral treaty in 1964 which regulates State-Church relations in Tunisia. Under the terms of this Modus Vivendi, the Tunisian state recognises the Catholic Church and its Prelate in Tunis (Art. 2), Papal authority over the nominations of clergy in Tunisia (Art. 9), allows the entry of such clergy onto its territory (Art. 8), and guarantees the free exercise of Catholic worship (Art. 1) as well as the propagation of Christian doctrine within Catholic places of worship and to children of Catholic parents within schools belonging to the Church (Art. 4). At the same time, the treaty forbids the Church from engaging in any form of political activity (Art. 3) and ceded almost the entirety of the Church's real estate holdings to the Tunisian state. After 1964, the Church only retained the Tunis Cathedral and its adjoining administrative 
buildings, Saint Jeanne d'Arc church in Tunis, the church buildings in La Goulette, Grombalia, and Sousse along with their rectories, two rectories in Hammam-Lif and Djerba, several dozen private schools run by Catholic congregations, and the Saint Augustine Clinic (Art. 6 and annexes). Additionally, the Modus Vivendi had a further consequence: the suppression of the Archdiocese of Carthage and the attendant honorific title of Primate of Africa. Although this element is not explicitly stated within the text, it is implicit in Art. 10 which recognises the prerogative of the Holy See in naming the "Prelate Nullius" of Tunis, rather than the Archbishop of Carthage. This change was actually effected by virtue of a Papal Bull released by Paul VI in July 1964 which erected the nullius prelature of Tunis within the territorial boundaries of the diocese of Carthage and placing it under the direct jurisdiction of the Holy See. Soumille (2003) argues that this was a specific demand on behalf of Bourguiba who rightly considered the re-creation of the Archdiocese of Carthage in 1884 to have been the result of French State machinations to promote the status of its imperial holdings. In sum, the treaty ensured the preservation of a Catholic presence in Tunisia, sought to isolate the Church in Tunis from French control, and dramatically restricted the Church's geographic footprint as well as its legal scope of operations. Internally, the most significant change within the Church in Tunisia was the 1968 Diocesan assembly. This assembly in July 1968 followed an extensive consultation process of Catholics throughout the country to redefine the mission and direction of the Church in its new external context formalised by the Modus Vivendi. What emerged from this assembly or quasi-Synod was the reorientation of the pastoral mission of the remaining Catholic actors towards secular activities to contribute to the development of Tunisian civil society. This precipitated the departure of many diocesan priests who remained committed to serving in a parish setting, whilst those who remained (under the dual influence of the Mission de France and the Pères Blancs) elected to pursue their religious mission in a largely secular capacity 
by participating in the development of Tunisia by working alongside Tunisians in either salaried or civil society roles. This decisive turn towards the Tunisian nation corresponded to the changing external conditions imposed by independence and the Modus Vivendi, but it also reflected changes already at work within the Church. In 1965, Mgr Michel Callens was incardinated as Prelate of Tunis; a Père Blanc trained in sociology and Arabic, Callens invested his Prelature with his congregation's commitment to integrating within their society of implantation. The reorientation of 1968 also reflected the overtures to modernity and to secular society already at work within the wider Catholic sphere, such as those initiated since the 1930s by social Catholic movements in the Francophone sphere which were influential in French North Africa (Action Catholique, Mission de France, Spirituality of Charles de Foucauld, and Christian tiers-mondisme). These initiatives were intellectually sustained by influential theological figures of the mid-twentieth century (Yves Congar, Marie-Dominique Chenu, Karl Rahner) and further consolidated by the Second Vatican Council in its formulation of the Church's role in responding to "circumstances of the life of modern man" (Gaudium et Spes:§54). The upheavals of 1968 within the Church in Tunisia thus echoed similar seismic shifts occurring across the Catholic world in that year (Raison du Cleuziou 2012; Horn 2018).

\section{Towards a more visible presence in Tunisia}

The years following national independence thus dramatically reoriented the mission and position of the Catholic Church in Tunisia. However, things have not remained static since 1968. In 1987, the Church in Tunisia organised a Synod to revaluate its position and mission after 22 years under the Prelature of Mgr Callens, during which time it had largely followed the twin policies of methodical discretion and secular engagement in civil society. 1990 marked a new phase in the life of the Church with the closure of the Synod and the 
publication of its final declaration in May, followed shortly thereafter by Mgr Callens's sudden death as a result of a malarial infection contracted in Lomé (Dornier 2000). Mgr Callens's tenure was followed by a two-year inter-regnum during which time Paul Geers, also a White Father, served as Diocesan Administrator. In 1992, Mgr Fouad Twal was named as Callens's successor as Prelate Nullius of Tunis.

Although the two central policies of the Callens era remain salient today, under Twal's tenure the Church underwent a series of cultural and demographic transformations which have attenuated its previous insistence on discretion as well as the priority it accorded to secular works ad extra over the liturgical life of the Church ad intra. Instead, under Twal's leadership, the Church entered a new phase defined by a renewed self-affirmation of the Church's legitimate place and visibility within (although not of) Tunisia. During this period, a greater diversification in terms of the national origins of the clergy and laity marked a break with its postcolonial identification with the French Church, and also ushered in a revival of liturgical solemnity and ritual which had fallen out of favour with the historic French clergy of the Callens era.

Originally from Jordan, Mgr Twal was the first Arab head of Church in Tunisia and, as such, made a strong impression both within the Church and in Tunisian society. Capitalising on his Arabic linguistic and cultural background to forge a strong working relation with the Tunisian State, Twal succeeded in re-elevating a Church that had lived in the shadows since the Modus Vivendi. In 1995 the Tunisian State raised no opposition when John-Paul II reinstated the Church in Tunisia to the status of diocese (although now with its seat in Tunis, not Carthage) and accorded the personal title of Archbishop to Mgr Twal. In April of the following year, Pope John-Paul II made a day-long state visit to Tunisia, consolidating the cordial relations between Tunisia and the Holy See. These two events elevated both the visibility of the Church in Tunisia and the stature of Twal himself who in 2008 would return 
to the Middle East as Latin Patriarch of Jerusalem. In 2010, the seat of Tunis was further elevated to the status of archdiocese by Benedict XVI.

In many instances, these changes were either imposed by external factors or initiated under Fr Geers as an application of the conclusion of the 1990 Synod. Mgr Twal is widely seen as the key force behind these trends, partly because he oversaw the completion of many changes, partly because he personally symbolised a shift in the Church's identity and priorities. However, under the administration of Fr Geers, the Church had begun to take hesitant steps towards a renewed self-affirmation and visibility, such as commissioning the external restoration of several church buildings. Twal invested this terrain fully, carrying out a substantive restoration of the Tunis Cathedral, rejuvenating the outward image that the Church gives of itself to its members and to Tunisian society. This was followed by other restorations under Twal's successor, Mgr Maroun Lahham: the restoration and reopening of St Felix church in Sousse in 2007, the restoration of Saint Fidèle church in La Goulette in 2010, of St Jeanne d'Arc in Tunis in 2010, the consecration of the chapel Notre Dame de l'Assomption in Bizerte in 2011, and the restoration of the Christian cemetery in Borgel in 2011 (Cugusi 2014:243). Twal also left a profound mark on the liturgical life of the Church, re-introducing a more rigorous and solemn form of worship in the Cathedral, and sought out new sources of clergy and women religious, inviting new congregations to send members to establish communities in Tunisia, whist older congregations and movements died off.

\section{The present array of the catholic church in Tunisia}

At present, the institutional Catholic Church today in Tunisia is represented by the Archdiocese of Tunis, the episcopal authority of which covers the entire national territory. In 2018, there were 71 women religious residing in Tunisia, 43 priests and brothers religious, and 17 members of secular third orders (see table 1). Whilst some members of these various 
orders serve or participate in the service of the territorial parishes, and two religious brothers from the Instituto del Verbo Encarnado (IVE) maintain a contemplative presence in the Charles de Foucauld Monastery in La Marsa, the majority of these are organised into communities which engage in social or educational work within Tunisian civil society. The most significant aspect of this work is the management of 10 private schools and day-care centres owned by the Catholic church and spread across Tunisia, in which are enrolled approximately 6,000 students, almost exclusively Tunisian and Muslim. Additionally, several clerics serve as chaplains to Christian prisoners in Tunis and Sfax and to the convalescent at the Church-owned Clinique Saint Augustin, whist the White Fathers in Tunis administer the Diocesan religious studies library in the medina, the Carthage study centre, and the historic Institut des Belles-Lettres Arabes (IBLA). 
Table 1: Diocesan, Religious and Lay Orders in Tunisia 2018. Source: Archdiocèse de Tunis 2018.

\begin{tabular}{|c|c|c|}
\hline Order & Communities & Members \\
\hline \multicolumn{3}{|l|}{ Feminine } \\
\hline Petites Sœurs de l'Assomption & 1 & 3 \\
\hline $\begin{array}{l}\text { Sœurs Blanches Missionnaires de Notre Dame } \\
\text { d'Afrique }\end{array}$ & 1 & 4 \\
\hline Filles de la Charité & 2 & 6 \\
\hline Sœurs Egyptiennes du Sacré Coeur & 3 & 13 \\
\hline Sœurs Franciscaines Missionaires de Marie & 2 & 15 \\
\hline Sœurs de Jésus Serviteur & 1 & 2 \\
\hline Missionaries of Charity & 1 & 4 \\
\hline Sœurs de Saint Joseph de l'apparition & 2 & 6 \\
\hline Salésiennes de Don Bosco & 2 & 9 \\
\hline Sœurs du Seigneur et de la Vierge de Matara & 2 & 5 \\
\hline Religieuses de Notre Damee de Sion & 2 & 3 \\
\hline Fidei Donum & 1 & 1 \\
\hline $\mathrm{T}$ & 22 & 71 \\
\hline \multicolumn{3}{|l|}{ Masculine } \\
\hline Diocesan Preists & & 4 \\
\hline Diocesan Preists residing outside of Tunisia & & 5 \\
\hline Fidei Donum & & 1 \\
\hline Verbe Incarné & & 5 \\
\hline Pères Blancs & & 18 \\
\hline Salésiens & & 4 \\
\hline Lazaristes & & 4 \\
\hline Chemin Néocatéchuménal & & 1 \\
\hline Seminarians & & 1 \\
\hline $\mathrm{T}$ & & 43 \\
\hline \multicolumn{3}{|c|}{ Lay movements } \\
\hline Comunità Missionaria Villaregia & 1 & 2 \\
\hline Memores Domini & 1 & 4 \\
\hline Chemin Néocatéchuménal & 1 & 6 \\
\hline Salam & 1 & 5 \\
\hline $\mathrm{T}$ & & 17 \\
\hline TT & & 131 \\
\hline
\end{tabular}


Whilst it is relatively easy to quantify the members of religious and lay orders, estimating the number of lay Catholics is more difficult. In many cases, their residency in Tunisia is transitory and the Archdiocese lacks the resources to keep close track of regular parish-goers. Cugusi (2014) estimated their presence to number 25,000 based on estimates provided by the Archdiocese. When questioned in 2018 during the fieldwork conducted for this article, the Archdiocese considered that the numbers had probably decreased by one or two thousand since 2014 owing to a diminution in the number of sub-Saharan African students enrolled in Tunisian universities. In any case, such numbers represent an estimate of the number of baptised Catholics residing in the country and are far superior to the number of regular practicing Catholics who attend weekly mass. Church officials estimate the current number of practicing Catholics to number between 1,000 and 2,000.

The territorial jurisdiction of the Archdiocese is composed of 10 parishes, which serve lay Catholic communities, but also certain communities of religious sisters. The Tunis Cathedral and Tunis Jeanne d'Arc serve congregations principally composed of sub-Saharan African students, irregular migrants from sub-Saharan Africa (aventuriers), a small historic population of European residents, and transitory migrants. These parishes also served the Catholic employees of the African Development Bank (ADB) during its residency in Tunis from 2003 to 2014. In the northern suburbs of the capital, the parishes of Carthage-La Marsa and La Goulette serve a diverse congregation composed of diplomatic staff, expatriates, and sub-Saharan migrants. The parish of the northern city of Bizerte serves several communities of religious sisters as well as a small sub-Saharan community. The parish in the coastal city of Sousse serves a congregation of European retirees and tourists, as does that of NabeulHammamet. The parish on the southern island of Djerba serves mainly for seasonal tourists and retirees. Finally, the parishes in the southern industrial cities of Sfax and Gabès serve congregations mainly composed of sub-Saharan African students and irregular sub-Saharan 
migrants. The small congregations of lay Catholics who live temporarily or permanently within Tunisia usually evolve separately from Tunisian society, separated by the barriers of language, culture, and socio-economic status. The lay Catholics who are probably the most integrated into Tunisian society are the European Christian spouses who have married Muslim Tunisian men and who can be found across the country, as well as small numbers of Europeans who have remained and worked there since independence.

\section{Dimensions of the church's transliminality}

The Catholic Church in Tunisia is a genuinely liminal institution, neither fully integrated within its national context, nor fully exposed to the mainstream Catholic world. The notion of liminality typically denotes a stage or status of ambiguity or marginality of status. Van Gennep $(1981,30)$ initially referred the idea of liminality to describe those "rites executed during the marginal period" of transition from one social state to another during culturally embedded rites of passage. In this characterisation, the notion was circumscribed to a transitory stage within a telelogical social framework. Turner $(1969,95)$ notably revised the concept, by arguing that there were not only liminal periods within cultures but also liminal personae (threshold people) who "are neither here nor there; they are betwixt and between the positions assigned and arrayed by law, custom, convention, and ceremonial". In the present analysis of the Catholic Church in Tunisia, I wish to further add to Turner's development of the concept of liminality by demonstrating how, in addition to personal identity with refence to "positions assigned", it can also characterise institutional processes of sensemaking in situations of cultural hybridity. A transliminal institution on this account describes an institution situated in a liminal or peripheral position with regards to two or more discrete institutional and cultural frameworks, but which does not simply exist 
passively between the two, but rather actively invests its sense of purpose and self within this liminality, seeking to mediate relations and to translate meaning between those frameworks. Situated in a liminal position with regards to both the Tunisian and the Catholic worlds, the Church in Tunisia after independence continued to exist through a constant process of translation and mediation between the religious world of Catholicism and the national world of Tunisia. Although a Christian Church, it has sought to immerse itself within its Muslim socio-cultural context. As such, it is situated at the threshold of the Catholic and the Muslim worlds: fully Catholic, but radically outside of the Catholic mainstream world; fully within the Muslim world, but radically outside of the Islamic faith. Although a religious entity, its principle modes of action and of discourse within Tunisian society are restricted to the secular domain: education, healthcare, charitable activities, participation in economic development. Catholic actors also maintain a liturgical life within the country, but that is both strictly restricted to the private sphere of its members and is also not perceived to be the pastoral specificity of the Church in Tunisia. As such, Catholic actors in Tunisia are constantly engaged in a process of translating their theological motivations and values into secular terms and forms of action which can be understood and accepted by their Tunisian interlocutors. $^{2}$ And although historically embedded within Tunisian society, the Catholic

\footnotetext{
${ }^{2}$ Habermas (2005) theorises such a process as the "institutional translation proviso", which is meant to allow religious actors to carry their private convictions over into the political public sphere in a manner that respects the secular neutrality of that space. However, the position of the Catholic Church in Tunisia with regards to this process is distinct from the liberal scenario envisaged by Habermas which is meant to accommodate the political participation of religious actors. In the present case, there is never any question of venturing into the political public sphere as the Catholic Church is forbidden to engage in political activities by virtue of article 3 of the Modus Vivendi. The specificity of the Catholic Church's position in Tunisia is that it does not have a Catholic constituency within the national public sphere. Therefore, any actions it takes or discourses it emits outside of the
} 
Church in Tunisia has never become (nor sought to become) fully integrated within the Tunisian national body. In the absence of a significant numbers of Tunisians converting to Catholicism and the constitution of an indigenous clergy, the Church retains a quasi-consular status at the periphery of Tunisian society because it is constituted almost exclusively by foreign nationals and because it is a non-Muslim religious organisation in a country where a reference to Islam remains entrenched within the national sense of identity. In the following section, I analyse this core characteristic of the Church in Tunisia through three dimensions: its self-narrative through scriptural references, its relation to national identification and nationhood, and its approach to mission and evangelisation.

\section{Scriptural references}

One way of understanding the profile of the Catholic Church in Tunisia is to interrogate its self-narrative, and particularly to consider the Biblical and theological references employed by Church actors in order to explain the identity and mission of their Church in the Tunisian context. A few such references are recurrent.

The first is to compare the Church in Tunisia to Jesus's early Nazarene years, the approximately 30 years in which Jesus lived in Nazareth prior to the moment when he publicly revealed himself as the Messiah and embarked upon his short public life as an itinerant predicator. This period is often referred to as the hidden years or the hidden life of Jesus in the Christian tradition. Whilst ancient accounts of Jesus's childhood do exist in the corpus of New Testament apocrypha (notably in the so-called infancy Gospels of James, Thomas, and Pseudo-Matthew), few details from this period appear given in the canonical

confines of the few church buildings it owns are de facto taken with non-Catholics or addressed towards non-Catholics. 
Gospels. In Luke, the period between the moment when the child Jesus remained in the temple in Jerusalem and when he began his public life as an adult are expedited in a few sentences: "Jesus went back to Nazareth with his parents and obeyed them... [He] became wise, and he grew strong. God was pleased with him and so were the people" (Lk 2, 51-52). The reference to Nazareth is notably central in the spirituality of Charles de Foucauld, a key reference for Catholics in Tunisia and through-out North Africa. Whilst the imitation of Jesus is central to all Christian tradition, Foucauld $(1924,26)$ modelled his asceticism with a reference to the Nazarene period of Jesus's life, emphasising anonymity, a silent presence amongst others in a context of material poverty, a search of for virtue through one's conditions of being rather than through one's words or actions. Jean-François Six $(2002,71)$ describes Nazareth as representing for Foucauld, "the human condition, the labours and days, an incessant attuning to circumstances and events, an impassioned quest to explore as best possible all of the data of existence, to advance in the knowledge of things and in the learning of how to live with others". For Catholics in Tunisia, the reference to this Nazarene period in Jesus's life echoes their own practice of the discretion and silence that characterises the Church's position within Tunisian civil society. Under the terms of the Modus Vivendi, but also according to the dominant view of Catholic actors in Tunisia, the Church should not engage in an open "ministry of the word" in this national context. Rather than pursuing an “explicit proclamation” of the Gospel, which would imply speaking directly to Tunisians about Jesus about his message, the favoured route is an "implicit" evangelisation, which consists in conveying the core of Jesus's message through acts of social good and especially through one's own manner of being in society. However, the Nazarene reference is also one that emphasises this period of silence as foreshadowing a period, perhaps distant, of open proclamation. As Bruno of the Salam Community in Sfax explains: "The Church is here for the Tunisian people. It is a presence, a sign, in order to become a proclamation". Whilst some 
actors categorically reject the idea of converting Tunisian Muslims to Christianity, for most their present liminal position in Tunisia is not an end in itself but a necessary stage of groundlaying in a much longer mission ordained by God.

Another Biblical reference evoked by Catholic actors and which raises similar themes is that of the Visitation of Mary. "The Church in the Maghreb, it's the Visitation. It's Mary in Nazareth", explains Sr Marie Malika, a member of the Soeurs Blanches. Again, this refers to a passage within the canonical Gospels prior to Jesus's public life (Lk 1,39-56). Immediately following the Annunciation in which she learned of her own pregnancy, Mary visits her cousin Elisabeth, herself pregnant with John the Baptist. No sooner has Mary greeted her cousin than the baby John leapt in Elisabeth's womb and Elisabeth was filled with the Holy Spirit (Lk 1,41). Fabia Nascimento, a lay member of Salam, explains the significance of this passage with regards to her mission in Sfax: "We try to be like Mary who visits her cousin Elizabeth carrying in her womb Jesus Christ. She cannot tell her cousin all that has happened to her, or about this child, but she still transmits Jesus to her cousin”. Again, the choice of this passage is significant in that it both emphasises the importance of a silent presence, and also in that it is chronologically situated prior to a moment of explicit announcement. Catholic actors in Tunisia generally agree that the moment of explicit and open evangelisation has not yet arrived there. Yet, some see the early stages of such transformation immanent in the political transitions brought about by the regime change in 2011 . The liberty of conscience introduced by the 2014 constitution, and the liberalisation of the state are seen in the conciliar theological sense as signs of the times, announcing a renewed relationship between the Church and the Tunisian people.

In 2011, the Archbishop of Tunis, Mgr Lahham, drew a parallel between the protestors in Tunisia and Jesus's first public preaching: 
The protagonists of the uprisings were the young, the jobless, the poor [...] Their demands echoed the first speech that Jesus delivered in the synagogue of Nazareth: The Lord has sent me to proclaim good news to the poor, to proclaim freedom to prisoners, to set the oppressed free LK 4,19 [...] These seeds of the Kingdom have matured especially outside the visible frontiers of the Church, and this is what caused our surprise. Therein lies a lesson in humility, as well as a reminder that only God is missionary. (Lahham 2011, no page number given) In this instance, it is significant that the Archbishop chose a passage not from the Nazarene period, but from Jesus's public life as predicator to argue that the young Tunisian protestors may not be Christian themselves (they are outside the visible frontiers of the Church) but their actions are bound within the larger announcement of Jesus's message. The Church and Tunisian society are seen as moving towards a common finality by virtue of the same divine force.

This idea is also apparent in a landmark pastoral letter published in 2014 by the assembled bishops of North African (CERNA), which characterises the Arab Spring events in eschatological terms:

The process underway recalls Exodus, the story of a people liberated from dictatorship and slavery. The revolution is analogous with the passage of the Red Sea, symbol of the desire for freedom, for justice, and for peace. The postrevolution is like the passage of a desert, long and difficult, the stake of which is to reclaim one's own history. Finally, democratic construction would be the arrival in a Promised Land, so long hoped-for. [...] Regarding our role in these passages, it resembles that of Jesus with the two disciples of Emmaus: Jesus approached them and he walked with them (Lk 24,15). To listen, to assist in discernment, to support the search for justice, for dignity and for liberty, but also 
for solidarity, through a patient journeying, with confidence and in prayer, these are our daily bread and commitment. (CERNA 2014, 6)

Again, the chronology of the scriptural reference here is revealing. At this point in the Gospel of Luke, Jesus has resurrected, but He has not yet revealed himself to his disciples. The passage goes on to explain that as Jesus walked with his disciples, "they were kept from recognising him" $(\mathrm{Lk} 24,16)$. Once again, as in his Nazarene period, Jesus is hidden in plain sight, but now his revelation is imminent as the course of history has accelerated. Moreover, Jesus in this passage does not explicitly tell them who he is, but rather accompanies them until "their eyes were opened and they recognized him" (Lk 24,31). The Churches in North Africa are not yet called upon to openly proclaim the Gospel, but the pastoral letter suggests that the time is approaching when the peoples of the region will recognise the divine nature of the Church that has patiently journeyed alongside them. A similar theme was echoed by many Church actors interviewed, such as Fr Jawad who described the 2011 revolution and the progressive growth in liberty of conscience as a "sign of the times outside of the visible frontiers of the Church"; Fr Jawad also echoed the Bishops and many Catholic actors by insisting on the role of God's will in establishing the timeline for such changes: "you cannot programme a conquest. We can only serve the Holy Spirit. [...] In Tunisia, there is a natural path towards maturity and the liberty of conscience". In this sense, the Church occupies its most appropriate role as a transliminal institution: maintaining a presence in the peripheral vision of Tunisian society whilst staying in union with the universal Church. Thus positioned, the mission of the institutional Church in Tunisia is to mediate between the Tunisian people and the universal Church until the former are ready to recognise it as the harbinger of Jesus's good news and to enter within the visible frontiers of the Church.

\section{Institutional religion and national identity}


The institutional Church in Tunisia is on the periphery of the Catholic mainstream world, but it is also on the periphery of the Tunisian nation. As previously discussed, the Church's current standing in the country is predicated upon a bilateral treaty between the Tunisian State and the Holy See. Tunisia has maintained a diplomatic mission to the Holy See since 1972 through its Ambassador residing in Berne, Switzerland; the Holy See maintains an Apostolic Nunciature in Algiers, whose remit includes both Algeria and Tunisia. Official actors of the Church (prelate, clergy, members of religious congregations, and lay members serving in an official capacity) are all foreign nationals designated by the Holy See to the Tunisian State, which delivers visas allowing them to work in a religious capacity for the Church. The Church also employs numerous Tunisian nationals, but not in roles involving the dissemination of Catholic doctrine or liturgical practice. Instead, they work in various secular capacities: teachers in Church-owned schools, doctors in the Saint Augustin Clinic, and maintenance and janitorial roles in the Cathedral and other church properties. Following independence and to the present day, the clergy included persons who had been born in Tunisia or who arrived at a young age and have resided for numerous decades in the country. However, these persons have not been naturalised as Tunisian citizens. In certain cases, they unsuccessfully requested Tunisian citizenship; the exception being one consecrated lay woman from France who, after numerous years in the country, succeeded in gaining Tunisian citizenship. This situation is markedly different from that in neighbouring Algeria, where many Catholic actors requested and obtained Algerian nationality (by virtue of the Evian Accords) including Cardinal Léon-Etienne Duval, Archbishop of Algiers from 1954 to 1988 . This difference is attributable to different types of settlements to emerge from the postcolonial period, the differing attitudes towards religious diversity and foreign intervention in both countries, and to the different strategies employed by the Catholic Church in both countries. The prolonged armed conflict that led to the end of French rule in 
Algeria forced Catholic actors there to make a starker choice between the two belligerents than in Tunisia where independence came about more gradually and peacefully.

When interrogated about their feelings of national identification, Catholic actors offered a range of answers, but none responded that they felt Tunisian. Actors' feelings of identification with their countries of origin is also often ambivalent. A phrase often evoked by those interrogated was that they felt "comfortable" [ bien $]$ or even "at home" $[$ chez moi] in Tunisia. However, when asked if they felt Tunisian, those same actors responded negatively. Sr Thérèse described this internal tension in these terms: "we need to recognise that we are foreigners here but that we are still citizens". In order to explain this apparent contradiction, Sr Thérèse offered a pragmatic explanation with regards to her sense of mission: "In order to accomplish my duty, I have to do my work as though I was going to live here my whole life". A similar tension is identifiable in the Charte de compagnonnage des communautés $d u$ Sud, a 1974 document laying out the core principles of mission for the Christian communities living in relative isolation in southern Tunisia: "We recognise that were are strangers, by virtue of our sociological membership and of our religious membership. [...] We admit that this foreignness [étrangéité] has its limits and that it is possible for us to reduce the distance that separates us from this people". Further, the document states that the communities of the South aspire to "live under the sign of compagnonnage", a term which refers to apprenticeships through guilds, but that also evokes the notion of accompanying or journeying alongside another, a theme discussed earlier in the context of CERNA's interpretation of the Arab Spring events. Such formulations illustrate the central characteristics of the transliminal ideal type laid out in the introduction of the article: institutional actors situated in a liminal position between discrete social spaces, but who are not isolated from those spaces, but rather use their position to act as mediators between those spaces. 
Whilst these points of view are still influential today, they are anchored in the missiological choices made in the early post-colonial period during the Callens era. Certain differences in the manner of national identification are discernible between younger and older generations of Catholic actors. The younger generation is more prone to refer to their nationality, to display symbols of national identification in their homes and offices, to speak in languages other than French within their communities, and to insist on their foreignness from Tunisia. Whilst the older generation do not profess to be Tunisian, they rarely identify themselves as nationals of their county of legal citizenship, usually France. For example, Sr Marie Malika, originally from France, explained that when she returns to her home country to visit family, she did not feel comfortable and that she did not "understand their mentality". This is partly attributable to the amount of time some have spent here, some having been in Tunisia for decades or having even been born here. But it is also an attribute of the older generation's sense of mission as focused on participation and presence within Tunisian civil society. Additionally, this generational difference is attributable to their respective national origins. Whilst the majority of the older generation originated from France or other Western European nations with imperial antecedents in North Africa, the newer generation are more often from the global South. The ethno-national diversification in the clergy and the laity of the Church in Tunisia has in certain respects changed its identity and its relation to Tunisia. By drawing together members from numerous different countries and linguistic traditions, the Church has adopted a transnational profile.

In this context, the question of French identity and the Church's historical and continued ties to France is particularly significant. Indeed, whilst the general issue of Catholics' foreignness highlights the Church's lack of indigenous implantation, its lack of specificity does not provide a substantial foil to the trope of Tunisian national identity. The cosmopolitan composition of the Catholic Church makes it non-Tunisian, but it does not make it a vehicle 
for the particular national interests of those Catholics who reside in Tunisia: Jordan, Egypt, Ivory Coast, Brazil... However, the historical support that the French state provided to the Archdiocese of Carthage during the Protectorate period (Renault 1992), and the perception that the Church in Tunisia today still retains a French identity is seen as a liability within the Church. Thus, many Catholic actors are keen to distance themselves from being identified with France. For example, Sr Thérèse from Egypt, laments that "many Tunisians believe that the Church is linked to colonisation. But it isn't the case. We are not France. We are a people in service [to others]". For some, the internal diversification of the Church offers lessons both to the historic European lay community and to Tunisians: "The French now see their [Christian] origins in the Orient, and that Arabs are not just Barbés [referring to a largely Algerian area in northern Paris]. And Tunisians see that Christians are not all colonists" (Fr Jawad interview, 2018).

Thus, in certain respects the internal diversification within the Church has eased its relationship with the Tunisia nation, introducing the prospect (not yet fully realised) of a Church presence disassociated from the colonial past within the public imaginary. Yet, this diversification has had contradictory effects on the transliminal character of the Church, through which it opened itself onto Tunisian society in the first place. It has necessitated that Catholics in Tunisia increasingly orient their work of mediation and translation inwardly to bridge distances of national, cultural, ethnic and linguistic difference within the Church. However, this work on the institutional self has been accompanied by an introspective turn, to the detriment of the Church's outward-looking transliminal work of mediation and translation between the Catholic world and Tunisian society. The re-establishment of a contemplative order in the country instantiates this introspective turn. As the Church has increasingly become concerned with overcoming its own internal divisions and maintaining unity within 
new expressions of Catholicity, it has invested less time and resources to its external relations. Further down I argue that this reflects a broader shift within Catholicism. Another theme that is increasingly privileged by younger Church actors in order to both mark a distinction between the Church and French colonialism and to legitimate the Church's continued presence in Tunisia is the history of the early Church in North Africa: "We are not the heirs of France, but of Cyprian, Monica, Felicity, and Augustin" (Fr Jawad interview, 2018). Instead of continuing to erect Cardinal Lavigerie or Charles de Foucauld as touchstones, the current trend within the Church is to recover the memory of Christian saints and martyrs whose history ties the Church to this territory prior to the existence of the French nation, but also prior to the emergence of Islam. Fr Silvio, Vicar General of the Tunis Cathedral, is at the head of this movement, initiating and participating in several projects to "rediscover the Christian Tunisia" such as leading youth groups on Christian thematic tours of the Carthage museum and maintaining a web blog devoted to Christian archaeology in Tunisia. $^{3}$

Despite the transnational currents within the Church, it still retains a European (and specifically French) orientation. This is partly the result of pragmatic considerations. Numerous exchanges continue with France and Italy: the current diocesan Vicar-General is a French national; during my time in Tunisia I met a seminarian from the French diocese of Vannes serving an apprenticeship in the parish of Jeanne d'Arc; student exchanges are organised with the diocese of Caligari in Italy. Most significantly, French continues to serve as the de facto liturgical and administrative language for the Church in Tunisia. As the clergy and the laity need a lingua franca to communicate amongst themselves during worship, in administrative settings, and socially, French continues to be the most accessible language,

\footnotetext{
${ }^{3}$ See: http://archeologiechretienne.ive.org/. The enthusiasm for Christian antiquity is somewhat of a return of history in this case, as it was a subject enthusiastically pursued by French clerics, scholars and colonial authorities during the nineteenth century (Alexandropoulos and Cabanel, 2000).
} 
especially given the growing number of Catholics arriving from Western Africa who often speak French. As Sr Thérèse explains, "French serves as a bridge between the different [ethno-national] communities".

However, there is currently a growing desire within the Archdiocese to introduce Arabic into the liturgical and working life of the Church. Mass is celebrated in Arabic once a month in the parishes La Marsa and in Jeanne d'Arc. Certain prayers of the regular weekly liturgy are now also regularly said in Arabic, such as the Pater Noster and the Sanctus. Tutorials are provided on the Archdiocese website and transliterations are provided during Mass in order to guide parishioners who are not fluent in Arabic. In 2018, the Archdiocese also organised sessions in liturgical Arabic for its clergy, so that the non-Arab priests in Tunisia can progressively learn to celebrate the Latin-rite mass in Arabic. Notably, these linguistic overtures are exclusively in classical Arabic, and never in Tunisian derja dialect. In this, the Catholic Church takes a different stance from the Evangelical and Pentecostal 'house churches' which have grown in recent decades, but also from the historically established Reformed and Anglican Churches, all of which provide some form of worship in Tunisian dialect (Boissevain 2015).

This difference in approach is partly attributable to the fact that the (modest) Arabisation that occurs within the Catholic Church is initiated and orchestrated by Arab clergy. As such, their primary conception of Arabisation refers to historical Arab Churches in the Levant, rather than to an imagined future Church in Tunisia. In celebrating the Mass in liturgical Arabic, they see themselves as creating a symbolic bridge with Eastern Catholic Churches, and serving the small Middle-Eastern Christian community present in Tunisia. This is different from the situation of the Protestant Churches in Tunisia, which are also transnational but which do not possess their own distinct Arabic liturgical traditions. A further factor to explain this difference concerns the divergence in Protestant and Catholic approaches to nation in 
their respective missiological outlooks. Evangelical and Pentecostal movements in Tunisia actively pursue the conversion of Tunisians, whilst the Reformed and Anglican Churches at least cater to a small converted Tunisian public. As mentioned, these Churches offer worship services in Tunisian dialect and in certain cases also host Tunisian Pastors or lay Tunisians who lead worship. According to Boissevain (2013:13), these "new [Tunisian] Christians seek through a new use of their language to confirm their indigenousness [autochtoneité], their rootedness and their attachment to Tunisia. At the same time, the mother tongue employed in a Christian religious context is reinvested with a Christian ideology and serves in a process of distinction from the ambient society, neighbours, family". As shall be discussed in the following section, the Catholic Church's position on these matters is more circumspect: it is wary at best with regards to conversion, it does not seek to affirm itself as integrated within the Tunisian nation, and yet it is also wary of claims of distinction which might be perceived as disparaging to Tunisian culture and Islamic religion.

\section{Missionaries without converts: The meaning of evangelisation in a resistant national}

\section{context}

Andrew F. Walls has argued that the history of the Christian Church is notably characterised by a central tension between two opposing tendencies. The "indigenising" principle holds that "in Christ God accepts us together with our group relations; with that cultural conditioning that makes us feel at home in one part of human society and less at home in another" (Walls 1999, 97). Yet, "along with the indigenising principle which makes his faith a place to feel at home, the Christian inherits the pilgrim principle, which whispers to him that he has no abiding city and warns him that to be faithful to Christ will put him out of step with his society; for that society never existed, in East or West, ancient time or modern, which could absorb the word of Christ painlessly into its system" (ibid, 98-99). 
Boissevain's research $(2013,2014 a, 2014 b, 2015)$ has demonstrated that for Evangelical Protestant Churches in Tunisia, their sense of mission within the country is centred on activities of proselytism and conversion. For these Churches the pilgrim principle appears to be dominant, and they are representative of what Jean-Paul Willaime (2014) has termed Christianisme de conversion, a form of Evangelical Christianity composed of a decentralised network of movements which intensively organise proselytising missions across the globe. This family of Christian Churches are particularly mobilised within the '10/40 window' of the 'resistant belt', a general area between the $10^{\text {th }}$ and $40^{\text {th }}$ parallels north of the Equator inhabited by the majority of the world's Muslims, Hindus, and Buddhists (Mézié 2008). Evangelical missionaries who come to Tunisia are committed and unapologetic about their commitment to announce in explicit terms the tenets of their faith and to convince Tunisians that they should become Christians through baptism.

The position of Catholic actors regarding conversion is far more circumspect. Evangelisation is a core commitment within Catholic doctrine: the "Church is missionary by her very nature" (Ad Gentes 1965:§ 2). Doctrine also stipulates that each bishop "as the ruler and centre of unity in the diocesan apostolate [should] see to it that apostolic activity is not limited only to those who are already converted, but that a fair share both of personnel and funds be devoted to the evangelization of non-Christians" (ibid: $§ 30$ ). However, what evangelisation should entail in terms of institutional positioning and missionary action is a topic of longstanding debate within the Catholic Church, and especially in the Maghrebi context.

Whilst it was a North African Bishop (Cyprian of Carthage) who first stipulated that Extra Ecclesiam nulla salus (outside of the Church, there is no salvation), the modern Catholic approach to mission in North Africa has tended to avoid overt forms of proselytism directed towards indigenous Muslims. A case in point: whilst the Missionaries of Africa (Pères blancs), founded by Cardinal Lavigerie in Algiers in 1868, led large-scale and successful 
evangelisation campaigns in sub-Saharan regions, conversions in the Maghreb were few. Oissila Saaidia (2015) has even argued that the Church's much-vaunted early successes amongst the Kabyle populations of Algeria were smaller than often supposed. In 1869, Lavigerie himself lamented that:

for twelve hundred years, Mohamedism has raised against the Catholic apostolate barriers almost insurmountable. None of the missions founded in the thirty countries where the Muslim religion reigns have produced discernible results; no nation, no fraction of a nation has been converted or even shaken in its errors by our missionaries. (Lavigerie 1869, 30)

Faced with this historical resistance, Lavigerie advised the members of his society to embed themselves within Muslim societies without seeking to obtain conversions which were not forthcoming. Henri Marchal, one of Lavigerie's most eminent successors in the Society of Missionaries of Africa, carried on this dialogic approach to missionary work in the Maghreb, emphasising the transmission of Evangelical values in terms understandable to the local culture and without aiming for the baptism of Muslims (Cuoq 1986). For Lavigerie and Marchal, Christian ministry in Muslim North African societies should be guided by three "rules of wisdom": to avoid proselytism and to concentrate on the "essential truths" of the monotheistic tradition; the practice of "all things to all" with tact and prudence through charitable works; and to conduct oneself and to present oneself as a "man of God" through acts of prayer and good will (Marchal 1938). These principles were in turn received and practiced by Marchal's own successors, such as in Robert Caspar's (1995) project to translate Catholic theology into terms comprehensible from an Islamic perspective, and in Christian de Chergé and Claude Rault's project of interfaith dialogue through the Rîbat al-Salâm network. Indeed, many Catholic actors engaged in interfaith exchanges in North Africa adopt a very wide interpretation of Lumen Gentium (1964), and maintain that by virtue of divine grace 
salvation is accessible to sincere non-Christians who seek God in other religious traditions. ${ }^{4}$ Gérard Demeersman (n.d.:35) argues further to this point that whilst the North African milieu is structurally resistant to "conversion transconfessionelle" (entry into communion with the Church through baptism), it is open to "conversion théologale" (a turning of the heart towards God through the influence of divine grace).

Whilst there are a range of views amongst Catholic actors in Tunisia regarding whether the Church should evangelise with the aim of baptising Tunisians, all those interviewed insisted on the central mission of bearing witness to Christian virtues through their actions and presence. As explained by F. Faustino, "Our mission here is one of witness and of silent presence" (Interview 2018). Moreover, all of those interviewed agreed that the Tunisian context is (at least at present) inappropriate for explicit evangelisation and condemned "proselytism". They also insisted that no group religious practices took place outside of the official places of worship or in private homes with the proper authorisation, in accordance with the terms of the 1964 Modus Vivendi: "Never outside of a church do we permit ourselves to talk about Jesus Christ" (Capobianco interview 2018). Within the confines of these conditions, most Church actors speak favourably of those conversions which do nonetheless occur and some openly anticipate a possible future in which the situation will be more favourable more explicit forms of evangelisation. On the other side of the Catholic spectrum, some are reticent if not hostile to the Church gaining disciples who are born into Muslim milieus. Fr Jean Fontaine, a senior White Father and former Director of IBLA, expresses this position particularly emphatically: "I am proud to have never baptised anyone in 62 years". Fr Fontaine explained the position in terms similar to Demeersman's explanation of conversion théologale: "a Muslim can follow Jesus without converting. He can be a musulman Christique”.

\footnotetext{
${ }^{4}$ The key passage for understanding their position is $\S 16$.
} 
Whilst this ambivalent position with regards to conversion is partly theologically motivated, it also reflects the reluctance of the institutional Church to act as a disruptive or overly proactive force within Tunisian society. A recurrent issue cited by Catholic actors regarding the prospect of accompanying Tunisian converts into the Church is the potential rupture this would cause between the convert and their social environment, indicating a resistance to the disruptive qualities inherent within the Christian pilgrim principle as characterised by Walls (1999). This discourse is particularly strong amongst historic older members of the Church in Tunisia. Fr Yvon Jutard, a diocesan priest born in Tunisia in 1928, explains that, "If [the conversion] has been thoroughly considered [murie] and it does not cause a rupture with the Tunsian social life, then it's good. Otherwise it's a problem and we should let things happen by themselves". For Fr Ferré, a White Father who has lived 23 years in Tunisia and who was formerly the director of the PISAI (Pontifical Institute for Arabic and Islamic Studies) in Rome, conversion often amounts to an unacceptable act of "cutting someone from their milieu".

The act of conversion can also compromise other forms of mission such as inter-religious dialogue to which the Missionnaires d'Afrique and Fr Ferré in particular are committed. Ferré cited the example of a Muslim academic who was a prominent member of the GRIC (Groupe de Recherches Islamo-Chrétien), but who became discredited amongst other Muslim members of the group when he converted to Christianity. For Sr Marie Malika, encouraging Muslim Tunisians to convert can amount to an irresponsible act: "There is no sense in proselytism [here]. It would leave them unrooted [On crée des déracinés]". Moreover, Sr Marie Malika, who has lived in Tunisia since 1970, reflects that "the longer we're here, the less we want to convert. We want them [Tunisians] to live more like Jesus Christ, but you don't do that by changing a label". 
Younger Catholics who have arrived more recently in Tunisia do not substantially diverge from institution's historically-embedded tendency towards the indigenising principle. Fr Albert Kondemore, a 37-year-old Père blanc who arrived in Tunisia in 2017, explains that "we don't want you to break with your society, your family", citing the example of a recent convert whose wife had left him upon discovering that he was preparing to be baptised. However, Fr Kondemore is also representative of other members of the new generation of Catholic clergy when he qualifies this position, recalling meeting a nun from Pakistan who had upbraided him for his reluctance to encourage Tunisians to convert: "She told me, 'For us [in Pakistan] that's what it is to be Christian. It means to be persecuted, to suffer!' That struck me. Is that really what it means to be a Christian?". This phrase is indicative of a cautious shift by younger, more cosmopolitan Catholics towards the pilgrim principle. A point of divergence on this topic between older and younger Catholics was that the latter were more prone to acknowledge the role of martyrdom in the Church's missionary history, especially the martyred saints of the early Church in North Africa: Cyprian, Felicitas, and Perpetua of Carthage. They are also more likely to refer to scriptural justifications for the social rupture associated with conversion (e.g. Mat 24:9-10, Lk 12:49-56, Lk 14:26-30) as well as Pope John Paul II's encyclical on the Church's missionary mandate, Redemptoris Missio which describes martyrs as "par excellence the heralds and witnesses of the faith" (1990: $§ 45)$. Ultimately however, Fr Kondomore insisted on the principle of discernment in the service of mission: "You can accomplish something more prophetic and more valuable that seeking out martyrdom. There are places where the Church has survived because it was able to discern". When Catholic actors discussed the social rupture that can result from conversion, their concerns centred on the potential negative reaction of the convert's social milieu, but also often on the tendency of converts themselves to reject their socio-cultural milieu of origin. With regards to societal reactions to conversion, the concern often expressed was that an act 
of conversion can elicit the ostracisation of the convert by their family and neighbours. $\mathrm{Sr}$ Marie Malika pointed out that there often exists a disjunction between the de jure liberty of conscience guaranteed by the 2014 Constitution and societal norms: "the laws since the Revolution have been very avant-gardiste, but you don't change a country in two minutes". Following independence under the Bourguiba regime, Tunisia developed a national relation to Islam that set it apart from other Arabo-Muslim societies, sometimes described as "Bourguibean Gallicanism", which describes the ideology and institutional practice establishing the primacy of the state over the religious sphere through a co-optation and systematic control of the latter (Frégosi 2004). Islam was recognised as the state religion until 2014, when the constitutional revision introduced a more ambiguous phrase identifying Islam as the religion of Tunisia (Art. 1). Whilst the Tunisian Constitution still restricts the office of the Presidency to Muslim Tunisians (Art. 74), it also guarantees liberty of belief, conscience, and religious practice (Art. 6) and all persons interviewed agree that state authorities are in practice less hostile to acts of conversion than under the Ben Ali regime. The country seems to be moving in a progressively liberal direction in this domain. In 2017 , a law was revoked which prohibited Tunisian women from marrying non-Muslim foreigners. That same year, President Béji Caïd Essebsi commissioned a report to adapt the country's legislative corpus so as to conform with the principles outlined in the new Constitution.

Yet whilst the Tunisian State legally guarantees freedom of conscience, Boissevain (2014a) notes that converts are still often perceived as religious, political and social traitors. At the political level, Boissevain argues that "the primary fear is that it undermines national unity by questioning the "natural' relationship between tunisianité and Islam" (Ibid:55). At the social level, "choosing to become Christian is interpreted as a choice formulated against everything in which [the convert] has been raised, as a global rejection of [their] society" (ibid:56). The connection between religious and national loyalty has also been observed in neighbouring 
countries. Direche (2011) reaches similar conclusions in Morocco where conversion to Christianity is often characterised as a form of treason to Islam but also to the nation. Pierre Boz $(2009,243)$ identifies a similar reaction in Algeria where historical conversions are "stained with reprobation because they are the product, according to certain Algerian historians, of 'treason', 'dishonour', and 'repudiation' [of Algeria]'. The other manifestation of social rupture often cited by Catholic actors is when the convert elects to reject their milieu, their culture, and their former faith as a result of their conversion. For Sr Araceli Medina, N.D.S., conversion "often translates into a rejection of Islam" and a larger rejection of the convert's social identity. Such forms of rejection are seen as disruptive to the convert's well-being, but they also pose a deeper problem for Catholics who have devoted their pastoral lives to living in harmony amongst Muslims and who often seek to promote greater mutual understanding between Christians and Muslims. In keeping with their commitment to interfaith dialogue, many Church actors argue that conversion to Christianity should not translate into a rejection of Islam.

Additionally, many Catholic actors interviewed noted with a certain unease the tendency of converts to proclaim their new faith publicly and proactively, in contrast to their own methodical discretion. Often a parallel is drawn between this situation and numerous passages in the canonical Gospels in which Jesus instructs a supplicant to remain silent regarding the healing or miracle that Jesus just performed, only for the supplicant to spread the news far and wide (e.g. Mk 7, 36; Lk 5, 14; Lk 8, 56). For Fr Jawad, this difference with regards to an open proclamation of the Christian faith is legitimised by virtue of national identity: "[Converted] Tunisians are less discreet than us, but we are in their home". In many instances, the theme of hospitality and respect for local sensitivities were invoked to explain why the Church, beyond any legal obligation, should maintain a low profile in Tunisian society - a requirement not imposed on converted Tunisians as they are legitimate members 
of the body politic and also a challenge to the binary identification between Tunisian nationality and Islamic religion.

Despite the lack of active proselytism, some Tunisians do become Catholics. Whilst the Archdiocese is reluctant to discuss the issue in much detail, they acknowledge that a small number of Church members are Tunisian converts. Different Catholic actors within the Diocese proffer differing estimates (the figures ranged from 50 to 100), and those with positions within the Prelature itself, who have access to solid figures, are most reluctant to advance a number. In most instances, converts do not make a direct transfer from Islam to Catholicism. Often, they are lapsed Muslims, atheists or agnostics or converts. Also, whilst some Tunisians are baptised in the Catholic Church, more have been baptised in a Protestant Church and subsequently became Catholics because they felt dissatisfied with the experience of their initial Christian community.

The phenomenon of conversion has become sufficiently prominent (and controversial) within North African Catholic dioceses, that the assembled Bishops of the region addressed the issue directly and publicly in 2014:

"The multiplication of means of communication and of human exchanges, as well as the more pronounced emergence of personal conscience has given rise in certain of our countries to new disciples of Jesus within our very ecclesial communities. Our Churches of the Maghreb have always banished from their practices any form of proselytism, which is neither respectful of conscience nor the path taught and practiced by Jesus. [...] We can only rejoice when new disciples join us, with the utmost freedom, conscious of the risk of being sometimes excluded from their communities of origin. We welcome them as a gift of God who excludes no one from his plan revealed in Jesus Christ" (CERNA 2014:14) 
Several elements are worth noting in this passage. The first is the very recognition of conversions. In previous decades, the North African Bishops tended to refrain from mentioning the phenomenon of conversion in such explicit terms in the context of their public declarations. In a major document published in 2000, CERNA identified the growing pluralism of North African societies, commenting that "the time when religion was the principal cement of a society seems revolved" (11). However, at that time the Bishops did not extend the analysis to recognise that one of the consequences of this social decomposition is the individualisation of religious identities, which includes the growth of conversions to Christian Churches. As Hervieu-Léger argues (1999:121), “conversions in modern societies are inseparable from the individualisation of religious adhesion and from the process of institutional differentiation through which emerge religious identities which are distinct from ethnic, national, or social identities”. Earlier still, in 1979, CERNA distanced itself from "kerygmatic" forms of Evangelical proclamation, insisting instead on the appropriateness of "agatopoiein" (acts of good conduct and charity) as a "theology of witness" appropriate to the social conditions of their specific context (14).

What is of further note in the 2014 passage cited above is that it seeks to establish a via media between different currents both within and without the Church. The Bishops are emphatic to reaffirm that their Churches do not proactively seek to convert local populations in North Africa. This message is in keeping with their historic position and serves as a reminder for newer Catholic actors who have an experience of mission in other cultural contexts where explicit forms of evangelisation are less controversial. However, this message is also a public statement aimed at North African state authorities to pre-empt any critiques that the acknowledgement of converts must imply the existence of proselytising practices. In this context, the opening sentence of the passage is particularly important as it situates the causation factors for conversions within North African societies themselves rather than 
within the Church. On the Bishops' account, the conversions are attributable to profound changes within these societies and to their increasing connectivity to the wider world. This is in line with the observation already made in 2000 concerning the increasing pluralism and the penetration of globalisation within Maghrebi societies (CERNA 2000). Such an interpretation of events is not just political posturing; it corresponds to established Catholic doctrine with regards to missiology which holds that conversion is an act of God's grace and cannot be attributed to human actors (Catechism of the Catholic Church 1993, §153). Indeed, this belief was repeated by almost all the Catholic actors interviewed in the context of this study: "It's God that converts a person's heart, not me or any other person" (Capobianco interview 2018). At the same time, the Bishops adopt a public position with regards to conversion and stress that the Church must welcome new disciples.

Thus, an examination of the meaning of mission and evangelisation for the Catholic Church within the Tunisian reveals a pragmatic application of the principles identifiably within its scriptural self-understanding and in its relation to national identity. In its liminal position of mediation between the Catholic and the Tunisian social worlds, the Church in Tunisia seeks to bear witness to the Gospel in terms understandable to the Tunisian national body, whilst also seeking to justify a narrative of salvation for Tunisian Muslims within the framework of Catholic doctrine.

\section{Conclusion}

The Catholic Church in Tunisia thus far portrayed is the product of a series of historical accommodations and adaptations from colonial triumphalism to transliminal discretion which have permitted it to maintain a secure presence within this region despite the loss of its imperial patron and of its parochial constituency. By this perhaps unlovely term of transliminality, may aim has been to convey the specific characteristics of an institution 
situated in a liminal or peripheral position with regards to two or more discrete institutional and cultural frameworks, which deploys the majority of its activities towards mediating relations or translating meanings between those frameworks.

Whilst the analysis completed thus far reveals how the Church has managed to maintain itself between two social worlds, this state of affairs has also raised numerous internal tensions within the Church regarding the legitimate role of the Church in a Muslim country, in a postcolonial setting, and in the context of globalised modernity. These tensions are particularly visible in pastoral and theological divergences between those historic Catholic actors who contributed in the establishment of the current status quo and new emerging actors whose religious consciousness is less influenced by the dual experience of decolonisation and Vatican II than by globalisation and John Paul II's pontificate. In particular, attention must be paid to the latent impact of John Paul II's rallying cry to revive the Church's self-affirmation against secular culture and to reinvest the public sphere through overt forms of evangelisation on emerging Church actors in Tunisia. Such tensions raise numerous questions which call for further investigation into the sociology of the Catholic Church in Tunisia and its sister Churches in North Africa.

\section{Reference list}

\section{Works cited}

Alexandropoulos, J., 2009. Entre archéologie, universalité et nationalismes : le trentième congrès eucharistique international de Carthage (1930), Anabases, 9, pp. 53-70.

Alexandropoulos, J. and Cabanel, P., 2000. La Tunisie mosaïque (diasporas, cosmopolitisme, archéologies de l'identité). Toulouse : Presses Universitaires du Mirail..

Archevêché de Tunis, 2018. Annuaire diocésain. Tunis: Archevêché de Tunis. 
Artaud de La Ferrière, A., 2019. Brothers and sisters in faith: the politics of transnational intra-faith solidarity between Western and Eastern Christians'. In Serrano Cornelio, Jayeel and Gauthier, François and Martikainen, Tuomas and Woodhead, Linda, (eds.), The Routledge International Handbook of Religion in Global Society. New York: Routledge.

Bava, S., 2016. Migrations africaines et christianismes au Maroc. De la théologie des migrations à la théologie de la pluralité religieuse. Les Cahiers d'Outre Mer, (2), pp.259-288.

Beckford, J.A., 2003. Social Theory and Religion. Cambridge: CUP.

Beïngar Moyangar, A., 1996. La présence des africains subsahariens en Tunisie. Tunis: Jeunesse chrétiennes Africaine en Tunisie.

Benedict XVI, 2010. In tunesia dioecesis tunetana ad gradum ac dignitatem archidioecesis attollitur iisdem servatis finibus. Available online: http://w2.vatican.va/content/benedict-xvi/la/apost_constitutions/documents/hf_benxvi_apc_20100222_tunetana.html

Bensaad, A., 2008. Les migrations subsahariennes en Algérie. Rapport de recherche, Consortium Euro-Méditerranéen pour la recherche appliquée sur les migrations internationales. Available online : http://cadmus.eui.eu/bitstream/handle/1814/7873/CARIM-RR_2?sequence=1. [Accessed 3 Aug 2018].

Beyer, P., 1999. Secularization from the perspective of globalization: a response to Dobbelaere. Sociology of Religion, 60(3), pp.289-301.

Boissevain, K., 2013. Devenir chrétien évangélique en Tunisie. Quelques aspects d'une conversion en pays musulman à la veille de la révolution (2009-2010). In Pons, Ch. (Ed.), Jésus, moi et les autres. Paris : CNRS Editions, pp. 147-185. 
Boissevain, K., 2014a. Des conversions au christianisme à Tunis. Histoire, monde et cultures religieuses, (4), pp.47-62.

Boissevain, K., 2014b. Migrer et réveiller les Églises: Diversification des cultes chrétiens en Tunisie. L’Année du Maghreb, (11), pp.105-121.

Boissevain, K., 2015. Prier Jésus en derja tunisienne. Le statut des langues dans le processus de conversion au protestantisme évangélique. In Achour-Kallel, M. (Ed.), Le social par le langage. La parole au quotidien. Paris : IRMC-Karthala.

Boubakri, H. and Mazzella, S., 2005. La Tunisie entre transit et immigration: politiques migratoires et conditions d'accueil des migrants africains à Tunis. Autrepart, (4), pp.149-165.

Casanova, J., 2013. Is secularization global? In Bub, G., and Luber, M., (Eds.), Neue Räume öffnen: Mission und Säkularisierungen weltweit. Regensburg: Verlag Friedrich Pustet.

Caspar, R., 1999. Pistes de réponses aux questions qu’on nous pose. Rome: PISAI.

Chergé, Ch., 2016. L'échelle mystique du dialogue. Ed. by Salenson, Ch. Paris: Bayard.

Communautés du Sud, 1974. Charte de compagnonnage des communautés du Sud. Archives of the Catholic Prelature of Tunis, unmarked box.

Conférence Episcopale de la Région Nord de l'Afrique (CERNA), 1979. Les chrétiens au Maghreb. Le sens de nos rencontres. Rome: CERNA.

Conférence Episcopale de la Région Nord de l'Afrique (CERNA), 2000. Les Eglises du Maghreb en l'an 2000. Malta: CERNA.

Conférence Episcopale de la Région Nord de l'Afrique (CERNA), 2014. Serviteurs de l'espérance. Place of publication not specified: CERNA.

Cuoq, J., 1986. Lavigerie, les Pères blancs, et les musulmans maghrébins. Rome : Société des Missionnaires d'Afrique. 
Cugusi, M.C., 2014. Una testimonianza silenziosa. Storia della Chiesa cattolica in Tunisia dal Trattato del Bardo alla 'rivoluzione dei gelsomini'. Doctoral thesis. University of Cagliari.

Cugusi, M.C., 2016. . Una testimonianza silenziosa. Storia della Chiesa cattolica in Tunisia dal Trattato del Bardo alla 'rivoluzione dei gelsomini'. Ariccia: Aracne.

Demeersman, G., no date given. Henri Marchal 1875-1957. : Une approche apostolique du monde algérien. Société des Missionnaires d'Afrique - Série historique $\mathrm{n}^{\circ} 15$. Available online: http://peresblancs.org/henri_Marchal_fr.pdf

Dirèche, K., 2009. Dolorisme religieux et reconstructions identitaires: Les conversions néoévangéliques dans l’Algérie contemporaine. Annales. Histoire, Sciences Sociales, Vol. 64, No. 5, pp. 1135-1162.

Direche, K., 2011. Mondialisation des espaces néo-évangéliques au Maghreb. Méditerranée, (1), pp.59-65.

Dornier, F., 2000. Les Catholiques en Tunisies au fil des ans. Tunis: Finzi.

Echeverria, R., 2004. L'Eglise catholique en Tunisie. Archives of the Bibliothèque Diocésaine de Tunis, 276.114.ETC.EGL.

Foucauld, C., 1924. Ecrits spirituels. Paris: J . de Gigord.

Frégosi, F., 2004. La régulation institutionnelle de l'islam en Tunisie. IFRI Policy Paper no. 4. Available online : https://www.ifri.org/fr/publications/enotes/regulationinstitutionnelle-de-lislam-tunisie-entre-audace-moderniste-tutelle

Habermas, J., 2005. Religion in der Öffentlichkeit. In Habermas, J., Zwischen Naturalismus und Religion. Frankfort: Suhrkamp Verlag, pp. 119-155.

Hervieu-Léger, D., 1999. Le pèlerin et le converti. Paris: Flammarion.

Horn, G.R., 2018. Quand l'esprit de Vatican II se mêle à l'esprit de «68 ». Tumultes, 50, 1, pp. 43-56. 
John Paul II, 1995. Praelatura territorialis tunetana ad statum condicionemque dioecesis attollitur. Availbale online: http://w2.vatican.va/content/john-paulii/la/apost_constitutions/documents/hf_jp-ii_apc_19950531_tunetana.html Lavigerie, 1869, Lettre à un supérieur de grand séminaire relativement à la fondation d'une société de missionnaires pour le Sahara et l'Afrique Central. Available online : http://peresblancs.org/16_Anthologie_textes_lavigerie1.pdf

Lefèvre, R., 2015. Tunisia: a fragile political transition. The Journal of North African Studies, 20(2), pp.307-311.

Lelong, M., 1970. La rencontre entre l'Eglise catholique et l'Islam en Tunisie de 1930 à 1968. Thèse complémentaire pour le Doctorat-ès- Lettres, Aix-enProvence.

Marchal, H., 1938. Les Grandes Lignes de l'Apostolat des Pères Blancs en Afrique du Nord musulmane. Tunis : IBLA, 1938.

Mézié, N., 2008. Les évangéliques cartographient le monde. Le spiritual mapping. Archives de sciences sociales des religions, (142), pp.63-85.

Michel P., 2017. Contribution to a Socio-History of the Relations Between "Nation" and "Religion": The Case of Catholicism. In Michel, P., Possamai, A. and Turner, B.S. eds, Religions, Nations, and Transnationalism in Multiple Modernities. Basingstoke: Palgrave Macmillan.

Modus Vivendi between the Government of the Tunisian Republic and the Holy See (1964). Archives of the Catholic Prelature of Tunis, Box Modus Vivendi 3.

Norris, P., and Inglehart, N., 2011. Sacred and Secular: Religion and Politics Worldwide. Cambridge: CUP.

Ouerghemmi, S., 2011. Les églises catholiques de Tunisie à l'époque coloniale : étude historique et architecturale. Doctoral thesis. Tours University. 
Raison du Cleuziou, Y., 2012. A la fois prêts et surpris : les chrétiens en mai 68. In Pelletier, D., and Schlegel, J.L., (Eds.), A la gauche du Christ. Paris : Seuil, pp. 357-388.

Six, J.-F., 2002. La postérité de Charles de Foucauld. ETVDES, 7/397, pp. 63-73.

Renault, F., 1992. Le cardinal Lavigerie : 1825-1892, l'Eglise, l'Afrique et la France. Paris:Fayard.

Saaidia, O., 2015. Algérie coloniale. Musulmans et chrétiens : le contrôle de l'Etat (18301914). Paris : CNRS.

Soumille, P., 2003. Église catholique et état tunisien après l'indépendance. In Delisle, Ph. And Spindler, M. (Eds.), Les relations Eglises-Etat en situation postcoloniale. Paris : Karthala, pp. 155-201.

Torelli, S.M., Merone, F. and Cavatorta, F., 2012. Salafism in Tunisia: challenges and opportunities for democratization. Middle East Policy, 19(4), pp.140-154.

Turner, V., 1969. Liminality and Communitas. The Ritual Process: Structure and AntiStructure. Chicago: Aldine Publishing, pp. 94-113.

Van Gennep, A., 1981 [1901]. Les Rites de Passage. Paris : Editions Picard.

Walls, A.F., 1999. The Gospel as Prisoner and Liberator of Culture. In James A. Scherer and Stephen B. Bevans (Eds.), New Directions in Mission and Evangelization [Vol. 3]. Maryknoll, NY: Orbis Books, pp 93-105.

Willaime, J.P., 2004. Le statut et les effets de la conversion dans le protestantisme évangélique. In Fath, S. (Ed.), Le protestantisme évangélique, un christianisme de conversion: Entre ruptures et filiations. Turnhout: Brepols Publishers.

Interviews conducted by the author

Abdias. Tertiary student residing in Siliana. Identifies as non-denominational Christian. Nationality: Ivory Coast. Born: 1998. Interviewed on 9 July 2018. 
Fr Jawad Alamat. Diocesan priest at La Marsa. Nationality: Jordanian. Interviewed on 3 July 2018

Ali. Lay Catholic parishioner residing in Sfax. Nationality: Tunisia. Born: 1960. Interviewed on 7 July 2018.

Mgr Ilario Antoniazzi. Archbishop of Tunis. Nationality: Italy. Born: 1948. Interviewed on 11 July 2018.

Conceiçao Aparecida Da Silva. Lay member of Salam community in Sfax. Nationality: Brazil. Born: 1971. Interviewed on 8 July 2018.

Sr Thérèse Aziz. Religious sister, Egyptian Sisters of the Sacred Heart (Catholic Coptic Church, head of Jeanne d'Arc Primary School, Tunis. Nationality: Egyptian. Interviewed on 4 July 2018.

Thibeault de Bruyn. Seminarian in Tunis, delegated on a one-year apprenticeship from the Diocese of Vannes in France. Nationality: French. Interviewed on 3 July 2018.

Stefano Capobianco. Lay member of the Chemin Néochatéchuménal, residing in Tunis. Nationality: Italian. Interviewed on 5 July 2018.

Fr Narcisee Djerambete Yotobumbeti. Priest, Congregation of the Mission (Lazarists), Pastor of La Goulette Parish. Nationality: Chad. Born: 1975. Interviewed on 12 July 2018. Fr André Ferré. Priest residing in Tunis, Missionnaires d'Afrique (Pères Blancs). Former director of PISAI in Rome and former liberairan of IBLA, Tunis. Nationality: French: Born: 1933 Interviewed on 6 July 2018.

Fausta Flamigni. Consecrated lay Catholic residing in Tunis, serves as secretary to the Archbishop, Memores Domini (Communion et Libération). Nationality: Italian. Born: 1957. Interviewed on 13 July 2018.

Fr Jean Fontaine. Priest residing in La Marsa, Missionnaires d'Afrique (Pères Blancs). Former Director of IBLA. Nationality: French. Born: 1936. Interviewed on 7 July 2018. 
Sr M. Françoise [Family name withheld]. Superior of Mission in La Goulette, Missionaries of Charity. Nationality: India. Born [Withheld]. Interviewed on 12 July 2018.

Fr Faustino Garcia Peña. Priest residing in Tunis, Salesians of Don Bosco. Head of Salesian school in Tunis. Nationality: Spanish. Born: 1965. Interviewed on 6 July 2018.

Fr Yves Jutard. Diocesan Priest residing in Sfax. Nationality: French. Born: 1928. Interviewed on 8 July 2018.

Fr Léon Kabore. Priest residing in Sfax, Missionnaires d'Afrique (Pères Blancs).

Nationality : Burkina-Faso. Born : 1982. Interviewed on 8 July 2018.

Komenan. Tertiary student residing in Sfax. Lay Catholic parishioner. Nationality: Ivory Coast. Born: 1998. Interviewed on 8 July 2018.

Fr Albert Kondemore. Priest residing in Sfax, Missionnaires d'Afrique (Pères Blancs).

Nationality: Burkina-Faso. Born: 1981. Interviewed on 6 July 2018.

Fr Nicolas L'Hernould. Diocesan priest in Tunis, Vicar General of the Archidocese of Tunis and Vicar of Jeanne d'Arc Parish in Tunis. Nationality: French. Born: 1975. Interviewed on 11 July 2018.

Sr Marie Malika. Religious sister residing in La Marsa, Soeurs des Missonnaires de Notre Dame d'Afrique (Søurs Blanches). Nationality French. Born : 1970. Interviewed on 7 July 2018 .

Bruno Marinho. Lay member of Salam community in Sfax. Nationality: Brazil. Born: 1986. Interviewed on 8 July 2018.

Mark. Tertiary student residing in Sfax. Lay Catholic parishioner. Nationality: Madagascar. Born: 1998. Interviewed on 7 July 2018.

Sr Araceli Medina. Religious sister residing in Nabeul, formerly worked there as a midwife, Religieuses de Notre-Dame de Sion. Nationality: El Salvador. Born: 1942. Interviewed on 13 July 2018. 
Sr Bruna Menghini. Religious sister residing in Aïn Draham, Soeurs Franciscaines Missionaires de Mairie. Nationality: Italian. Born: 1937. Interviewed on 11 July 2018. Fr Luis Miguel Martinez. Abbot of the Charles de Foucauld Monastery, La Marsa, Instituto del Verbo Encarnado. Nationality: Argentina. Born: 1978. Interviewed on 6 July 2018. Marzouk. Lay Catholic parishioner residing in Sfax. Nationality: Tunisia. Born: 1960. Interviewed on 7 July 2018.

Fr Silvio Moreno. Priest, Instituto del Verbo Encarnado. Serves as Pastor of the Tunis Cathedral. Born: 1982. Nationality: Argentinian. Interviewed on 4 July 2018.

Fabia Nascimento Da Silva. Lay member of Salam community in Sfax. Nationality: Brazil. Born: 1980. Interviewed on 8 July 2018.

Parfait. Tertiary student residing in Sfax. Lay Catholic parishioner. Nationality: Cameroun. Born: 1997. Interviewed on 7 July 2018.

Fr Dominico Paterno. Priest residing in La Manouba, Salesians of Don Bosco. Head of Salesian primary school in La Manouba. Nationality: Italian. Born: 1955. Interviewed on 9 July 2018.

Sr Agnès Perrin. Religious sister residing in Nabeul, Religieuses de Notre-Dame de Sion. Nationality: Franc. Born: 1935. Interviewed on 13 July 2018.

Thevie. Tertiary student residing in Sfax. Lay Catholic parishioner. Nationality: Gabon. Born: 1992. Interviewed on 8 July 2018.

Fr Dominique Tommy-Martin. Diocesan priest residing in Aïn Draham. Nationality: French. Interviewed on 5 July 2018.

Fr Daniel Vitz. Priest, Instituto del Verbo Encarnado. Serves as Interim Vicar of the Tunis Cathedral. Nationality: USA. Born: 1977. Interviewed on 11 July 2018. 
Fr Léonce Zinzere. Priest currently studying at PISAI in Rome, former resident of IBLI in Tunis from 2004-06 and 2010-16, Missionnaires d'Afrique (Pères Blancs). Nationality: Burkina-Faso. Born:1980. Interviewed on 10 July 2018. 